\title{
Yeast heat shock mRNAs are exported through a distinct pathway defined by Riplp
}

\author{
Claudio A. Saavedra, ${ }^{1,2}$ Christopher M. Hammell, ${ }^{1}$ Catherine V. Heath, and Charles N. Cole ${ }^{3}$ \\ Department of Biochemistry, Dartmouth Medical School, Hanover, N ew Hampshire 03755 USA
}

\begin{abstract}
We reported previously that heat or ethanol shock in Saccharomyces cerevisiae leads to nuclear retention of most poly(A) ${ }^{+}$RNA but heat shock mRNAs (encoding Hsp70 proteins Ssalp and Ssa4p) are efficiently exported in a process that is independent of the small GTPase Ran/Gsplp, which is essential for most nucleocytoplasmic transport. To gain further insights into proteins essential or nonessential for export of heat shock mRNAs, in situ hybridization analyses to detect mRNA and pulse-labeling of proteins were used to examine several yeast mutant strains for their ability to export heat shock mRNAs following stress. Riplp is a 42-kD protein associated with nuclear pore complexes and contains nucleoporin-like repeat sequences. It is dispensable for growth of yeast cells under normal conditions, but we report that it is essential for the export of heat shock mRNAs following stress. When SSA 4 mRNA was induced from a G AL promoter in the absence of stress, it was efficiently exported in a strain lacking RIP1, indicating that Riplp is required for export of heat shock mRNAs only following stress. Npl3p, a key mediator of export of poly(A)+ RNA, was not required for heat shock mRNA export, whereas Rsslp/Glelp, a NES-containing factor essential for poly(A) ${ }^{+}$RNA export, was also required for export of heat shock mRNAs after stress. High-level expression of the HIV-1 Rev protein, but not of Rev mutants, led to a partial block in export of heat shock mRNAs following stress. The cata suggest a model wherein the requirement for $\mathrm{Npl} 3 p$ defines the mRNA export pathway, the requirement for Riplp defines a pathway used for export of heat shock mRNAs after stress, and additional factors, including Rsslp/Glelp and several nucleoporins (Rat7p/Nup159p, Rat2p/Nup120p, and Nup145p/Rat10p), are required in both pathways.
\end{abstract}

[Key Words: RNA export; heat shock; RIP1; hnRNP; RSS1/GLE1; Rev]

Received July 1, 1997; revised version accepted August 28, 1997.

A distinguishing feature of eukaryotic cells is the nucleus, a distinct subcellular compartment separated from the cytoplasm by the double-membraned nuclear envelope. Embedded within the nuclear envelope are nuclear pore complexes (NPCs) that serve as the only known channels for transport between the nucleus and the cytoplasm (for review, see Davis 1995; Panté and A ebi 1996). T ransport of macromolecules through N PCs is signal-mediated, saturable, and energy dependent. Considerable progress has been made in recent years in identifying (1) receptor mol ecules that recognize nucl ear localization signals (N LSs) within karyophilic proteins and mediate interactions between these proteins and NPCs, (2) a small Ras-like GTPase (Ran in metazoan cells and Gsp1p/Gsp2p in Saccharomyces cerevisiae) and its accessory proteins, which play a central role in nuclear protein import, and (3) distinct components of

\footnotetext{
1These authors contributed equally to this work.

2Present address: Department of Molecular Biology, University of Geneva, Geneva, Switzerland.

${ }^{3}$ Corresponding author.

E-MAIL charles.cole@dartmouth.edu; FAX (603) 650-1128.
}

N PCs required for nuclear protein import (for review, see Görlich and Mattaj 1996; Hicks and Raikhel 1996; Corbett and Silver 1997; Nigg 1997). The existence of permeabilized cell systems has allowed direct study of nuclear protein import in vitro and played an important role in elucidating the molecular details of this process (Adam et al . 1990; M oore and Blobel 1992; Schlenstedt et al. 1993).

In contrast, we know considerably less about the export of macromolecules from the nucleus. The same GTPase system (Ran/Gsplp) is believed to be required for this process, as defects in RN A export occur rapidly when yeast or mammalian cells carrying temperaturesensitive alleles of Gsplp/Ran, its GTPase activating protein (Rnalp), or its nucleotide exchange factor (Prp20p) are shifted to the nonpermissive temperature (A mberg et al. 1992, 1993; Forrester et al. 1992; Kadowaki et al. 1992; Shiokawa and Pogo 1974; Wong et al. 1997). Proteins that associate with nascent pre-mRN As within the nucleus and package them into heterogeneous nuclear ribonucleoprotein (hnRNP) particles contain nuclear export signals (NESs) (Michael et al. 1995). For example, the yeast hnRNP protein Npl3p 
has been shown to be a key mediator of RNA export signals (Lee et al. 1996). In addition, several yeast nucleoporins (N up82p, N up84p, N up85p, N up120p, N up133p, N up145p, Nup159p, and N pl4p) have roles specifically in RN A export, as strains harboring mutant alleles of some or disruptions of others show temperature-dependent defects in mRNA export but not in nuclear protein import (Doye et al. 1994; Fabre et al. 1994; Wente and Blobel 1994; Aitchison et al. 1995; Gorsch et al . 1995; Heath et al. 1995; Hurwitz and Blobel 1995; Kraemer et al . 1995; Li et al . 1995; DeHoratius and Silver 1996; Goldstein et al. 1996; Murphy et al. 1996; Siniossoglou et al. 1996; Dockendorff et al. 1997).

Competition experiments indicate that export from the nucleus of distinct classes of RNA molecules requires class-specific factors (Jarmolowski et al. 1994). The existence of such factors creates the potential to regulate nuclear transport so that only certain types of macromolecules are transported under certain conditions or to enable the transport of RNA molecules that would otherwise be retained in the nucleus. For example, HIV-1 Rev protein facilitates the export of introncontaining mRN As (Fischer et al. 1994). The export activity of Rev requires the presence of a leucine-rich NES in Rev (Malim et al. 1991) and appears to target Rev response element (RRE)-containing and intron-bearing HIV-1 mRN As to an export pathway that shares components with those requi red for export of $U$ snRN As and $5 S$ RNA, but not mRNA, tRNA, or rRNA (Fischer et al. 1995; Fritz et al. 1995).

Y east Riplp is a 42-kD polypepti de identified as a twohybrid interactor with HIV-1 Rev (Stutz et al. 1995). Similar two-hybrid screens led to the identification of the related mouse and human proteins, Rab/hRIP (Bogerd et al . 1995; Fritz et al. 1995). Y east Riplp contains a unique carboxy-terminal domain of $\sim 80$ amino acids. The amino-terminal $75 \%$ of Riplp contains many XXFG repeats and is most closely related to the repeat domain of the yeast nucleoporin Rat7p/N up159p (Gorsch et al. 1995; Kraemer et al. 1995). This sequence similarity suggests that Riplp may al so be a nucleoporin, and nuclear rim staining was seen using antibodies to Riplp (Stutz et al. 1995). Mammalian hRIP/Rab was detected primarily in the nucleoplasm (Fritz et al. 1995). It is not yet clear whether yeast Riplp and hRIP/Rab are homologs or whether Riplp is a component of NPCs or an NPC-associated protein.

RNA export is regulated following heat shock and other forms of stress in S. cerevisiae (Saavedra et al. 1996). Following stress, poly(A) ${ }^{+}$RNA accumulates within yeast nuclei, but stress also induces transcription of heat shock genes. Synthesis of inducible heat shock proteins requires that these heat shock mRNAs be exported to the cytoplasm. We showed previously that SSA 4 mRNA, encoding stress-inducible Hsp70, is efficiently exported following heat or ethanol shock and that its export is unaffected by mutations in components of the Ran/Gspl system (Saavedra et al. 1996).

Here we report the identification of factors required for export of heat shock mRNAs following stress in yeast.
Riplp is required, but no defect in export of mRN A was seen under normal growth conditions $\left(23^{\circ} \mathrm{C}-37^{\circ} \mathrm{C}\right)$ in cells disrupted at RIP1. In the absence of stress in cells lacking Riplp, export of SSA4 mRN A expressed from a GAL promoter occurred efficiently, indicating that export of SSA4 mRNA requires Riplp only following stress. High-level expression in yeast cells of HIV-1 Rev, but not of a mutant form of Rev lacking a functional NES, partially prevented the nuclear export of heat shock mRN As. Export of heat shock mRN As after stress was not dependent on functional $\mathrm{N} \mathrm{pl3p}$ but did require Glelp/Rsslp, an NES-containing protein essential for nuclear export of poly(A)+ RN A (Del Priore et al. 1996; Murphy and Wente 1996) and also shown by two-hybrid analyses to interact with Riplp (Murphy and Wente 1996). The data suggest a model wherein the requirement for $\mathrm{N}$ pl3p defines the mRN A export pathway, the requirement for Riplp defines a distinct pathway used for export of heat shock mRNAs after stress, and additional factors, including Rsslp/Glelp and several nucleoporins (including Rat7p/N up159p, Rat2p/N up120p, $\mathrm{N}$ up145p), are required in both pathways.

\section{Results}

Riplp is essential for nuclear export of heat shock mRNAs following cellular stress

In a previous report, we showed that cellular stress (heat or ethanol shock) causes accumulation of poly $(A)^{+}$RN A within yeast nuclei but that heat shock $m R N$ As are transcribed and exported efficiently (Saavedra et al. 1996). During the course of those studies we learned that yeast cells lacking the smal I N PC-associated protein Riplp are partially compromised for Rev-dependent export of RREcontaining RNAs but showed no defects in cellular growth or nuclear processes at either $23^{\circ} \mathrm{C}$ or $37^{\circ} \mathrm{C}$ (Stutz et al. 1995). We tested whether Riplp might be involved in the selective export of heat shock mRN As following stress by comparing the patterns of localization of poly $(A)^{+}$RN A and SSA 4 mRN A (expressed from a highcopy plasmid and encoding stress-inducible Hsp70) in wild-type cells and in cells deleted for RIP1. Interestingly, SSA 4 mRNA accumulated in nuclei of $\Delta$ ripl cells heat-shocked at $42^{\circ} \mathrm{C}$ for $1 \mathrm{hr}$ (Fig. 1l). Very little SSA 4 mRNA was visible when these cells where grown at $23^{\circ} \mathrm{C}$ (Fig. $1 \mathrm{G}$ ) or shifted to $37^{\circ} \mathrm{C}$ (Fig $1 \mathrm{H}$ ). Furthermore, in $\Delta$ ripl cells shifted to $42^{\circ} \mathrm{C}$ for $1 \mathrm{hr}$, the poly $(\mathrm{A})^{+} \mathrm{RN} A$ signal was exclusively nuclear (data not shown), whereas in wild-type cells shifted to $42^{\circ} \mathrm{C}$, a faint signal for $\operatorname{poly}(\mathrm{A})^{+} \mathrm{RNA}$ is detected in the cytoplasm following heat shock (Saavedra et al. 1996; data not shown) and most likely reflects the export of a variety of heat shock mRNAs produced following stress. We also examined the effect of ethanol shock on export of SSA 4 mRN A at $23^{\circ} \mathrm{C}$ in $\Delta$ ripl cells (Fig. 2). Following ethanol shock, SSA 4 mRN A accumulated within nuclei of $\Delta$ ripl cells, indicating that the requirement for Riplp for export following stress does not merely reflect a high-temperature threshold for inactivation of the export function of NPCs. Together, these results provide evidence that 


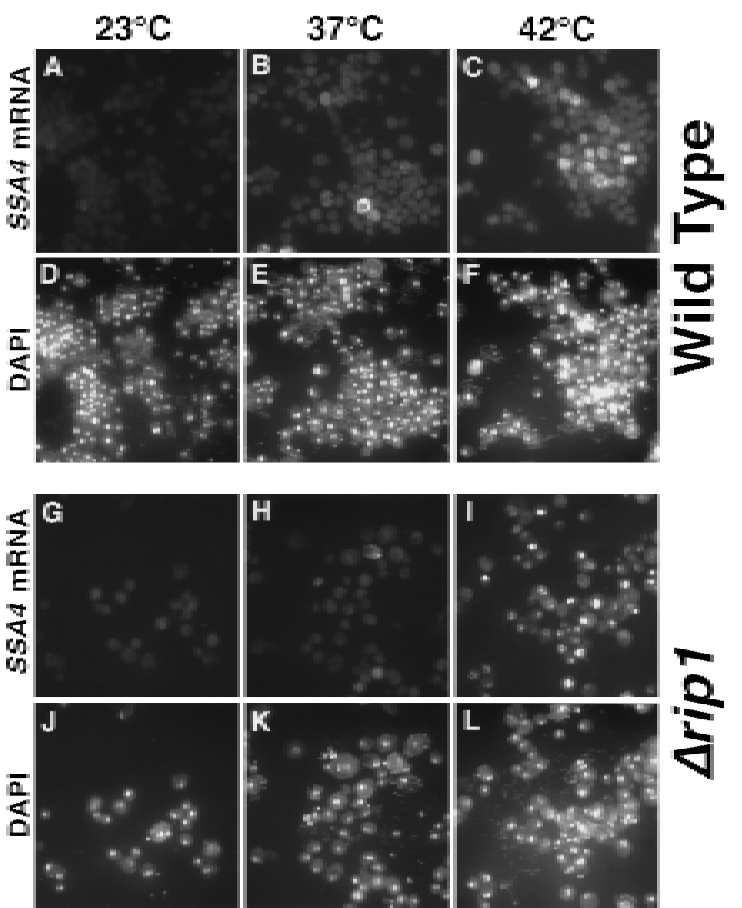

Figure 1. Riplp is required for export of SSA 4 mRN A following heat shock. Wild-type (FY23) or $\Delta$ rip1 (CHY 119) cells were maintained at $23^{\circ} \mathrm{C}(A, D, G, J)$ or shifted to $37^{\circ} \mathrm{C}(B, E, H, K)$ or $42^{\circ} \mathrm{C}(\mathrm{C}, \mathrm{F}, \mathrm{I}, \mathrm{L})$ for $1 \mathrm{hr}$ before processing for in situ hybridization to detect SSA 4 mRN A (A-C, G-I). Cells were al so stained with DAPI (D-F, J-L) to permit visualization of the DNA within nuclei. Shown are the same fields of cells examined by in situ hybridization or stained with DAPI. The SSA 4 mRNA fluorescent signal was variable from cell to cell, most likely reflecting varying copy numbers of the SSA 4 plasmid in different cells.

Riplp plays an essential role in the export of heat shock mRN A following stress.

In our previous studies, we examined the trafficking of SSA4 mRNA and the closely related SSA 1 mRNA following stress but did not examine expression of other heat shock genes. To determine whether Riplp is required for the export of other classes of heat shock mRN A, we radiol abeled cells with $\left[{ }^{35} \mathrm{~S}\right]$ methionine plus $\left[{ }^{35}\right.$ S]cysteine and compared the patterns of protein synthesis in wild-type and $\Delta$ ripl cells (Fig. 3A). Cells were labeled for 10-min periods prior to or at different times following heat shock. In wild-type cells, a range of heat shock proteins comprised the primary labeled products synthesized as early as 15 min after heat shock (Fig. 3A). Some of these reflect enhanced expression of proteins produced at lower levels under normal growth conditions (e.g., Ssalp), whereas others represent heat shock proteins that are synthesized only or primarily following stress (e.g., Ssa4p, Hsp104p). Following heat shock, the background labeling, representing a broad spectrum of cellular proteins synthesized under normal growth conditions, virtually disappeared. In contrast, in $\Delta$ ripl cells a pattern of translation persisted after heat shock that resembles that seen in both wild-type and $\Delta$ ripl cells prior to stress but became less intense as cytoplasmic
mRN As present prior to heat shock turned over. N ote particularly the dark band migrating just bel ow Hsp104p in $\Delta$ ripl cells; this band was nearly undetectable in wildtype cells heat-shocked for $15 \mathrm{~min}$ but persisted during the heat shock period in $\Delta$ ripl cells.

Those bands that represent heat shock proteins produced constitutively continued to be translated during stress, reflecting their preferential translation. Heat shock proteins that reach high levels only following heat shock (e.g., Ssa4p and Hsp104p) were produced in $\Delta$ ripl cells at levels substantially lower than in wild-type cells and with different kinetics. Although the rates of synthesis of induced heat shock proteins in wild-type cells were declining within $60 \mathrm{~min}$ of a shift to $42^{\circ} \mathrm{C}$, their levels were still increasing in $\Delta$ ripl cells. Although cells maintai ned at a very low density $\left(\right.$ e.g., $\left.\mathrm{OD}_{600}<0.10\right)$ contain essentially no SSA 4 mRN A (Stutz et al. 1997), low levels of SSA 4 mRNA are produced as cells reach higher densities, and it is probable that most of the Ssa4p synthesized following heat shock in $\Delta$ ripl cells derives from enhanced translation of SSA 4 mRNA produced prior to heat shock. However, the increase in the rate of synthesis of Ssa4p 60 min after heat shock in $\Delta$ ripl cells may also reflect some export of SSA 4 mRN A late in the heat shock period. The in situ hybridization results (Fig. 1) clearly show that most SSA 4 mRNA is prevented from leaving the nucleus in $\Delta$ ripl cells. The data shown in Figure 3A indicate that the production of several other classes of heat shock proteins was dramatically reduced in $\Delta$ ripl cells, suggesting that Riplp is important for the export of multiple classes of heat shock mRNA.

We also examined SSA4 mRN A levels using a primer extension assay (Fig. 3B). Analysis of rRN A level s in each sample (Fig. 3B) indicated that primer extension analyses were performed using approximately equal cell equivalents of RNA. Very low but detectable levels of SSA4 mRNA were present in both wild-type and $\Delta$ ripl cells

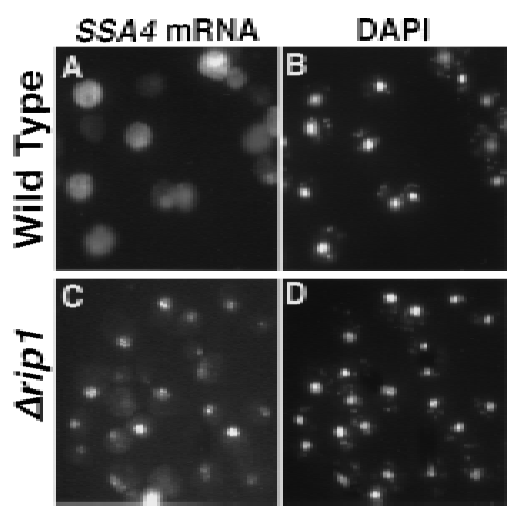

Figure 2. Riplp is required for export of SSA4 mRN A following ethanol shock. Wild-type (FY23) or $\Delta$ ripl cells (CHY119) were incubated at $23^{\circ} \mathrm{C}$ and shocked by addition of ethanol to $10 \%$ for $1 \mathrm{hr}$. Cells were processed for in situ hybridization and were al so stained with DAPI to permit detection of DN A within nuclei. (A) Wild-type cells, in situ hybridization; (B) the same field of cells as in A stained with DAPI; (C) $\Delta$ ripl cells, in situ hybridization; (D) the same field of cells as in C stained with DAPI. 
A

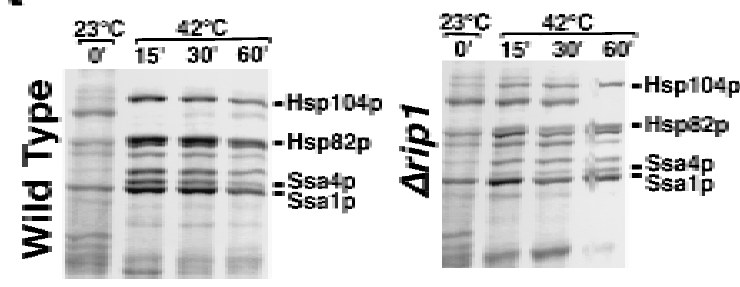

B

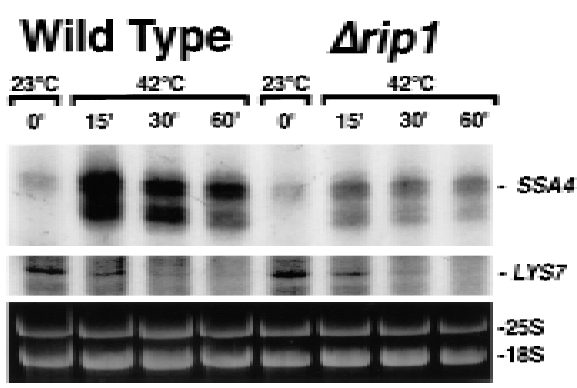

Figure 3. (A) Patterns of protein synthesis following heat shock. Wild-type cells and cells containing a disruption of RIP1 were grown at $23^{\circ} \mathrm{C}$, processed as described in Materials and M ethods, and radiol abel ed for $10 \mathrm{~min}$ at $23^{\circ} \mathrm{C}$ or shifted to $42^{\circ} \mathrm{C}$ and label ed for the final $10 \mathrm{~min}$ of a 15-, 30-, or 60-min period of heat shock at $42^{\circ} \mathrm{C}$. (B) Quantitation of specific mRN A levels by primer extension. SSA 4 and LYS7 mRN A levels were examined in wild-type (lanes 1-4) and $\Delta$ ripl cells (lanes 5-8) immediately prior to heat shock (lanes 1,5) and following 15 (lanes 2,6), 30 (lanes 3,7$)$, or $60 \mathrm{~min}($ lanes 4,8$)$ at $42^{\circ} \mathrm{C}$. To ensure that all primer extension analyses were performed on RN A samples derived from approximately the same number of cells, rRNA level s in each sample were examined by el ectrophoresis of aliquots of each sample in a $1 \%$ agarose gel, which was stained with ethidium bromide and photographed.

grown at $23^{\circ} \mathrm{C}$. SSA $4 \mathrm{mRNA}$ increased dramatically following the shift to $42^{\circ} \mathrm{C}$, but to a lower extent in $\Delta$ ripl cells than in wild-type cells. This may reflect a lower stability for the SSA 4 mRNA that accumulates in the nuclei of $\Delta$ ripl cells. As a control, we al so analyzed LYS7 mRNA. This mRNA declined from similar levels and with essentially identical kinetics in wild-type and $\Delta$ ripl cells (Fig. 3B).

To determine whether export of SSA 4 mRNA was dependent on Riplp under all conditions or only following stress, we examined the local ization of SSA 4 mRN A expressed from the GAL1 promoter in $\Delta$ ripl cells. N o SSA 4 mRN A was detected when cells were grown on glucose (data not shown) or raffinose (Fig. 4A). When cells were incubated for $2 \mathrm{hr}$ at $23^{\circ} \mathrm{C}$ in the presence of $2 \%$ gal actose, SSA 4 mRN A was present throughout the cell (Fig. 4B). This indicates that SSA 4 mRNA can be exported from the nucleus by at least two pathways: at $23^{\circ} \mathrm{C}$, Riplp is not required for export of SSA $4 \mathrm{mRN} A$, and this mRN A may be exported using the conventional poly $(A)^{+}$ RNA export machinery; at $42^{\circ} \mathrm{C}$, SSA 4 mRNA export requires Riplp (Fig. 1) and is also independent of the Ran/Gsplp GTPase machinery (Saavedra et al. 1996).
Because Riplp appears to be a nucleoporin whose re peat region is not essential, we wondered whether disruption of RIP1 caused any abnormalities in N PC distribution that could be involved in transport defects. We compared wild-type cells and cells disrupted for RIP1 by indirect immunofluorescence using either an antiRat7p/N up159p antibody or the RL1 monoclonal antibody that recognizes multiple repeat-containing yeast nucleoporins and observed a normal nuclear rim-staining pattern (C. Heath and C. Cole, unpubl.).

The essential yeast hnRNP protein Npl $3 p$ is not required for export of heat shock mRNAs

$\mathrm{N} \mathrm{pl3p}$ is an essential mediator of the export of poly $(\mathrm{A})^{+}$ RNA in yeast (Lee et al. 1996). To determine whether $\mathrm{N} \mathrm{pl3p}$ is required for export of heat shock mRNAs, we examined the localization of poly $(A)^{+}$RNA and SSA 4 mRNA in cells carrying the npl3-1 and npl3-17 alleles and expressing SSA 4 from its own promoter from a highcopy plasmid. As reported previously, poly(A $)^{+}$RN A accumulated in the nuclei of npl3-1 cells shifted to $37^{\circ} \mathrm{C}$ for $1 \mathrm{hr}$ (Fig. 5A, h), but the block to export was incomplete as some cytoplasmic signal remained. Following a shift to $42^{\circ} \mathrm{C}$, poly $(A)^{+}$RN A was detected primarily in nuclei, indicating that less poly $(A)^{+}$RN A was exported in npl3-1 cells following heat shock than at the nonpermissive temperature of $37^{\circ} \mathrm{C}$. Little or no SSA 4 mRN A was detected at $23^{\circ} \mathrm{C}$ (Fig. $5 \mathrm{~A}$, a) or $37^{\circ} \mathrm{C}$ (Fig. $5 \mathrm{~A}$, b), whereas it was primarily cytoplasmic following heat shock at $42^{\circ} \mathrm{C}$ (Fig. $5 \mathrm{~A}, \mathrm{C}$ ). This indicates that $\mathrm{N} \mathrm{pl} 3 \mathrm{p}$ is not required for efficient export of SSA 4 mRNA following stress. Essentially identical results were obtained with the npl3-17 allele (data not shown), even though this is a tighter allele than npl3-1, and the defect in poly $(\mathrm{A})^{+} \mathrm{RNA}$ export at $37^{\circ} \mathrm{C}$ in this strain was more complete than in npl3-1 cells. We also examined the pat-

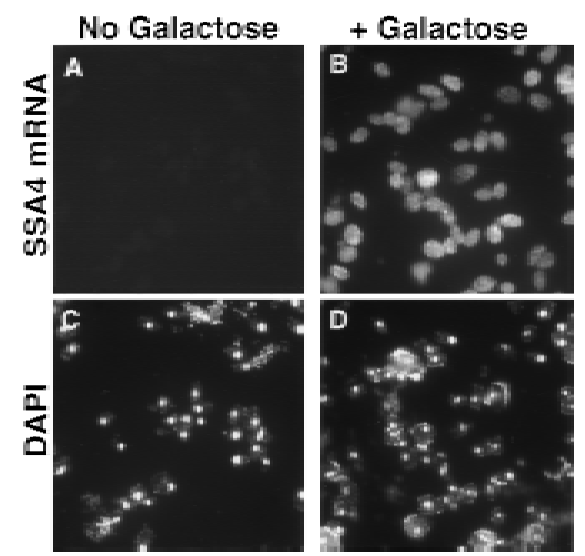

Figure 4. Export of SSA 4 mRNA under nonstress conditions does not require Riplp. $\Delta$ ripl cells, containing a CEN plasmid encoding Ssa4p under control of a GAL promoter, were grown on media containing $2 \%$ raffinose $(A, C)$ or shifted to media containing $2 \%$ galactose for $30 \mathrm{~min}(B, D)$ before processing for in situ hybridization using an SSA 4 probe $(A, B)$. The same fields of cells shown in $A$ and $B$ were also stained with DAPI $(C, D)$. 

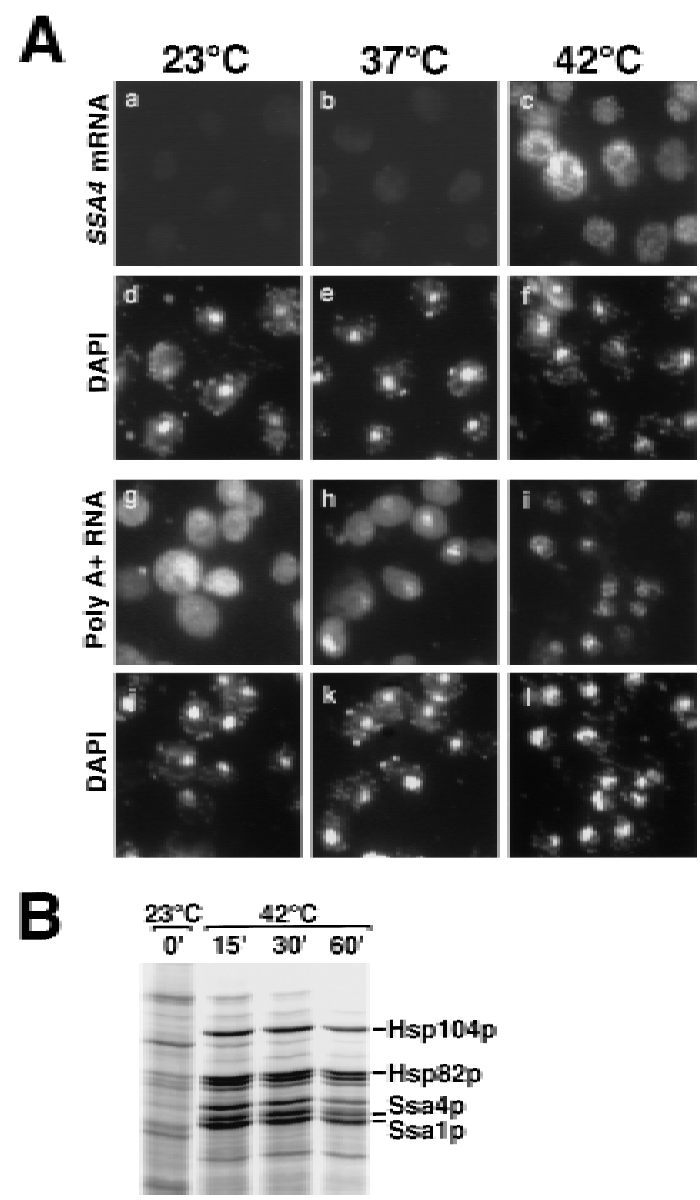

Figure 5. $\mathrm{Npl} 3 p$ is not required for export of heat shock mRN A s foll owing heat shock. (A) In situ hybridization to detect SSA 4 mRN A (a-c) and bulk poly $(A)^{+}$RN A ( $\left.g-i\right)$ in npl3-1 cells incubated at $23^{\circ} \mathrm{C}$ or shifted to $37^{\circ} \mathrm{C}$ or $42^{\circ} \mathrm{C}$ for $1 \mathrm{hr}$. The same fields of cells analyzed by in situ hybridization were al so stained with DAPI $(d-f, j-I)$. (B) Pattern of protein synthesis in npl3-17 cells incubated at $23^{\circ} \mathrm{C}$ or shifted to $42^{\circ} \mathrm{C}$ for 15,30 , or $60 \mathrm{~min}$.

tern of protein synthesis in heat-shocked npl3-17 cells (Fig. 5B) and found it to be indistinguishable from the wild-type pattern. We conclude that $\mathrm{N} \mathrm{pl3p}$ is not required for the export of heat shock mRNAs following stress.

High-level expression of HIV-1 Rev protein interferes with efficient export of SSA 4 mRNA following stress in yeast

HIV-1 Rev possesses a nuclear export signal required for the export of Rev itself and RRE-containing mRNAs (Malim et al. 1991; Fischer et al. 1994, 1995). Microinjection into Xenopus oocyte nuclei of a high level of the leucine-rich Rev NES conjugated to bovine serum albumin (BSA) inhibited the nucleocytoplasmic export of 5S RNA and U small nuclear RNAs (snRNAs) but did not affect export of rRNA, tRNA, or poly $(A)^{+}$ RNA (Fischer et al. 1995). Because export of SSA 4 mRNA following stress is dependent on the presence of Riplp (Fig. 1) and Rev functions to facilitate the export of RRE-containing mRNAs even in yeast (Stutz and Rosbash 1994), we examined the effects of high-level expression of HIV-1 Rev on poly(A $)^{+}$and SSA 4 mRN A export in wild-type yeast cells. Plasmids encoding either wild-type Rev or the M 10 export-defective Rev mutant, under control of the GAL10 promoter, were introduced into yeast cells carrying a high-copy SSA 4 plasmid. The M 10 Rev allele contains two missense mutations within the Rev activation domain/NES and does not facilitate the export of RRE-containing RN As in either yeast (Stutz et al. 1995) or mammalian cells (M alim et al. 1991). Although Rev interacts efficiently with Riplp and hRIP/Rab in two-hybrid assays (Bogerd et al. 1995; Fritz et al. 1995; Stutz et al. 1995), the ability of mutant Rev activation domains to function in vivo closely correlates with their ability to interact with hRIP/Rab/Riplp in two-hybrid assays (Bogerd et al. 1995; Stutz et al. 1996).

We induced production of wild-type or M10 Rev by addition of $2 \%$ galactose for $4 \mathrm{hr}$. As assayed by Western blotting using an anti-Rev antiserum, both Rev and $\mathrm{M} 10$ were induced to comparable levels by this treatment (Fig. 6A). Following induction at $23^{\circ} \mathrm{C}$, cells were shifted to $42^{\circ} \mathrm{C}$ for $30 \mathrm{~min}$ to induce transcription from the SSA4 promoter. Expression of wildtype Rev caused partial inhibition of the export of SSA 4 mRNA (Fig. 6B, cf. panel $G$ with panel C), whereas SSA4 mRNA export was normal in heat-shocked cells maintained in raffinose (Fig. $6 \mathrm{~B}$, panel $\mathrm{C}$ ). Expression of the M10 mutant did not interfere with the export of SSA4 mRNA (Fig. 6B, panel O). This suggests that wild-type Rev is able to titrate an important mediator of SSA 4 mRNA export following stress. We note that only a minority $(\sim 30 \%)$ of cells expressing wild-type Rev show clear nuclear accumulation of SSA 4 mRNA. Most likely, there is a correlation between Rev levels and the degree of accumulation of SSA4 mRNA in nuclei. Natural cell-to-cell variation in copy numbers for both the Rev and SSA4 plasmids likely results in substantial differences in actual Rev and SSA4 mRNA levels.

We al so examined the distribution of poly $(A)^{+} R N A$ in cells $\left(23^{\circ} \mathrm{C}\right)$ induced to express wild-type Rev or the $M 10$ mutant from a GAL promoter. Induction of Rev and M 10 expression for $4 \mathrm{hr}$ caused no detectable alteration in the distribution of poly (A) ${ }^{+}$RNA (Fig. 6C), demonstrating that the partial inhibition of SSA 4 mRN A export in cells expressing a high-level of Rev and shifted to $42^{\circ} \mathrm{C}$ is not likely to be attributable to any general inhibition of RN A export by Rev.

Rsslp/Glelp is required for export of both poly $(A)^{+}$ RNA under normal conditions and heat shock mRNAs following stress

Previously, we identified Rsslp as a high copy suppressor of the rat7-1 mutation (Del Priore et al. 1996). Murphy and Wente (1996) al so identified this protein (which they called Glelp) and demonstrated that Rssip/Glelp con- 

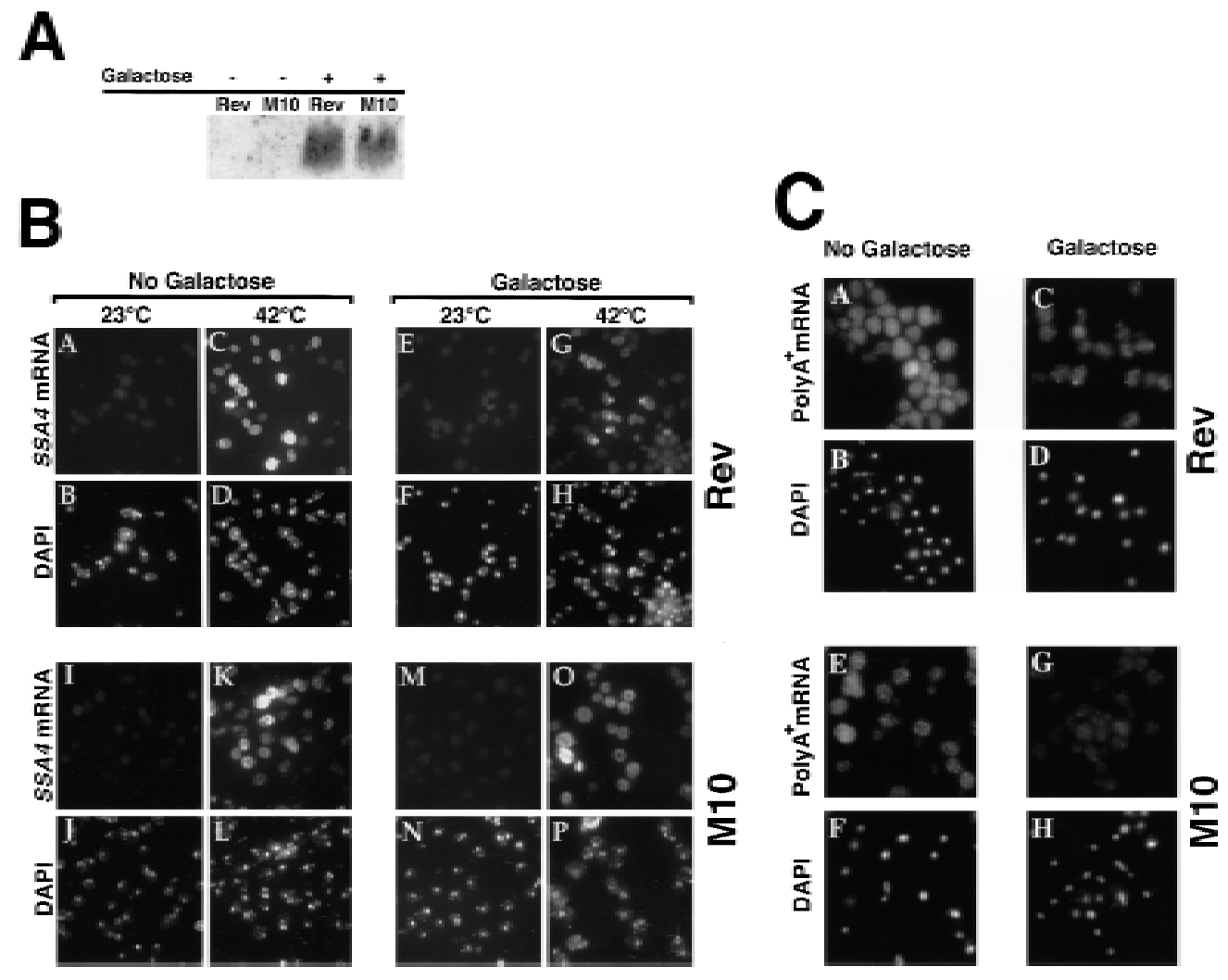

Figure 6. High-level expression of HIV-1 Rev interferes with export of heat shock mRNAs. Wild-type cells harboring plasmids encoding wild-type Rev or the M 10 mutant of Rev, under control of a GAL promoter, were grown in media containing $2 \%$ raffinose. Expression of Rev or M 10 was induced by shifting to $2 \%$ galactose for $4 \mathrm{hr}$. Subsequently, cells were shifted to $42^{\circ} \mathrm{C}$ for $30 \mathrm{~min}$. (A) Western blot to examine levels of Rev and M 10 protein. Extracts were prepared following $4 \mathrm{hr}$ of incubation in media containing $2 \%$ galactose. (B) In situ hybridization to detect SSA 4 mRN A (A,C,E,G,I,K,M ,O). Cells were al so stained with $D A P I(B, D, F, H, J, L, N, P)$. (C) In situ hybridization to examine the distribution of poly $(A)^{+}$RN A in cells expressing high levels of Rev $(A, C)$ or $M 10$ (E,G). Cells were incubated overnight at $23^{\circ} \mathrm{C}$ in media containing $2 \%$ raffinose $(A, E)$, shifted to media containing $2 \%$ galactose, and incubation was continued for $4 \mathrm{hr}(C, G)$. Cells were then processed for in situ hybridization. The cells shown in A, C, E, and G were al so stained with DAPI to show the location of the nucleus (B, $D, F$, and $H$, respectively).

tains a NES essential for its function. Strong nucl ear accumulation of poly $(A)^{+}$RNA was seen when cells were depleted for Rss1p/Glelp (Del Priore et al. 1996) or in cells carrying temperature-sensitive alleles of RSS1/ GLE1 shifted to the nonpermissive temperature (Murphy and Wente 1996). To understand further the role of Rsslp, we prepared a series of temperature-sensitive alleles of RSS1 (V. Del Priore and C.N. Cole, unpubl.).

We examined mutant cells carrying the rss1-37 allele for their ability to export SSA4 mRNA when heatshocked at $42^{\circ} \mathrm{C}$ (Fig. 7). There was modest nuclear accumulation of poly(A) $)^{+}$RN A in mutant cells grown at $23^{\circ} \mathrm{C}$ (Fig. 7A, a) and strong accumulation of poly $(A)^{+}$ RNA in the nuclei of $100 \%$ of the cells when they were shifted to $37^{\circ} \mathrm{C}$ for $1 \mathrm{hr}$ (panel b). In this strain, SSA 4 mRN A accumulated in the nuclei of cells shifted to $42^{\circ} \mathrm{C}$ (panel c), and there was little or no increase in the rate of synthesis of those heat shock proteins whose increased production requires export of newly transcribed heat shock mRNAs (Fig. 7B, cf. Fig. 3). This indicates that Rsslp is required for efficient export of RNAs both through the conventional mRNA export pathway and through the distinct pathway used for export of heat shock mRNAs following stress. We also examined the effect of loss of functional Rssip/Glelp on N PC distribution by comparing wild-type cells and cells carrying the rss1-37 allele. No changes in N PC distribution were seen in cells carrying the rss1-37 mutant al lele incubated at $23^{\circ} \mathrm{C}$ or shifted to $37^{\circ} \mathrm{C}$ or $42^{\circ} \mathrm{C}$ for $1 \mathrm{hr}$ (data not shown).

\section{Discussion}

Cells respond to stress at multiple levels to enable them to adjust to rapid changes in their environment and to recover from stress when stress conditions have passed (for review, see Lindquist 1986; Jost and Lindquist 1988; Lindquist and Petersen 1990; M orimoto et al. 1994; Morimoto 1993; Panniers 1994; Sierra and Zapata 1994). The experiments presented in this paper indicate that stress-induced heat shock mRN As are exported through a pathway that is independent of several but not all of the factors required for normal mRN A export. A model for these partially overlapping transport pathways is 
A
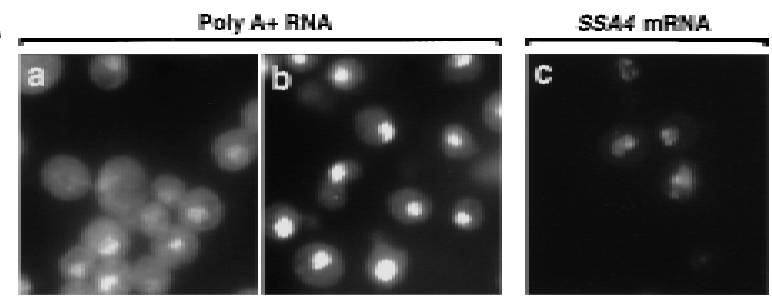

B

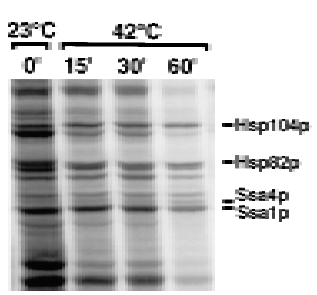

Figure 7. Rsslp/Glelp is required for export of heat shock mRNAs following stress. (A) In situ hybridization in rssl-37 cells. (a) poly $(A)^{+}$RNA in cells incubated at $23^{\circ} \mathrm{C}$; (b) poly $(A)^{+}$ RNA in cells shifted to $37^{\circ} \mathrm{C}$ for $1 \mathrm{hr}$; (c) SSA 4 mRN A in cells heat-shocked at $42^{\circ} \mathrm{C}$ for $1 \mathrm{hr}$. (B) Pattern of protein synthesis in rss1-37 cells incubated at $23^{\circ} \mathrm{C}$ or shifted to $42^{\circ} \mathrm{C}$ for 15,30 , or $60 \mathrm{~min}$. Radiolabeling occurred during the last $10 \mathrm{~min}$ of incubation.

shown in Figure 8. In S. cerevisiae, export of heat shock mRN As (Fig. 8, left), but not bulk poly(A) ${ }^{+}$RNA (Fig 8, right), depends on the nucleoporin-like N PC-associated Riplp (Fig. 1) but does not require N pl3p (Fig. 5), a key mediator of poly(A) ${ }^{+}$RNA export (Lee et al. 1996) or components of the Ran/Gsplp GTPase system (Saavedra et al. 1996). The N ES-containing protein Rsslp/Glelp is required for the export of both poly $(A)^{+}$RNA under nonstress conditions (Del Priore et al. 1996; Murphy and Wente 1996) and heat shock mRNAs following stress (Fig. 7). This factor may al so have roles in the export of other classes of RNA. There are likely to be additional factors required for export of both bulk poly $(A)^{+} \mathrm{RNA}$ under normal conditions and SSA 4 mRNA following stress, and these as yet unidentified factors may be required for export of other classes of RNA as well. In addition, there is likely to be at least one factor (X in Fig. 8) which binds specific elements in heat shock mRN As and has a role analogous to that of $\mathrm{N} \mathrm{pl3p}$ for export of poly $(A)^{+}$RN A under normal conditions. The same subset of nucleoporins required for export of $\operatorname{poly}(A)^{+}$ $m R N A$ is also required for export of heat shock $m R N A s$ following stress and may also be needed for export of other classes of RN A.

Previous evidence for the existence of multiple RNA export pathways comes primarily from studies in Xenopus oocytes, where it was shown that radi ol abeled RN As microinjected into nuclei were exported efficiently and that their export could be competed by unlabeled RN As of the same class but not by RN As of other classes (Jarmolowski et al. 1994). This indicates that, at least in Xenopus, the limiting export factors are specific for single classes of RNAs. Other studies focused on the HIV-1 Rev protein, a small RNA-binding protein that shuttles in and out of nuclei (Meyer and Malim 1994) and is able to facilitate the export of intron-containing mRN As that contain sequences to which Rev can bind (RRE) (Fischer et al. 1994). BSA coupled to the Rev NES was exported following microinjection into Xenopus oocyte nuclei and was able to inhibit the export of coinjected $U$ snRNA and 5S RNA but not mRNA, rRNA or tRNA (Fischer et al. 1995). These and other studies sug gest that Rev directs intron-containing HIV-1 mRN As to an RN A export pathway normal ly used for export of nonpoly (A )+RN As (Fridell et al. 1996; Fritz and Green 1996), most likely $5 S$ RN A and U snRN As. The machinery involved in Rev-dependent export appears to be conserved among distantly related organisms, as Rev functions in S. cerevisiae in a manner that is also dependent on RRES within RNAs and the presence of a functional NES within Rev (Stutz and Rosbash 1994).

In the studies reported here, we used two assays to monitor RN A export. The first involves in situ hybridization to detect poly(A) ${ }^{+}$(A mberg et al. 1992) or specific mRN As (Saavedra et al. 1996). In situ assays are quite sensitive for detection of partial defects in RN A export, as modest accumulation of RNA in nuclei is readily seen, even when cytoplasmic RN A levels remain high. However, this assay is insensitive for determining

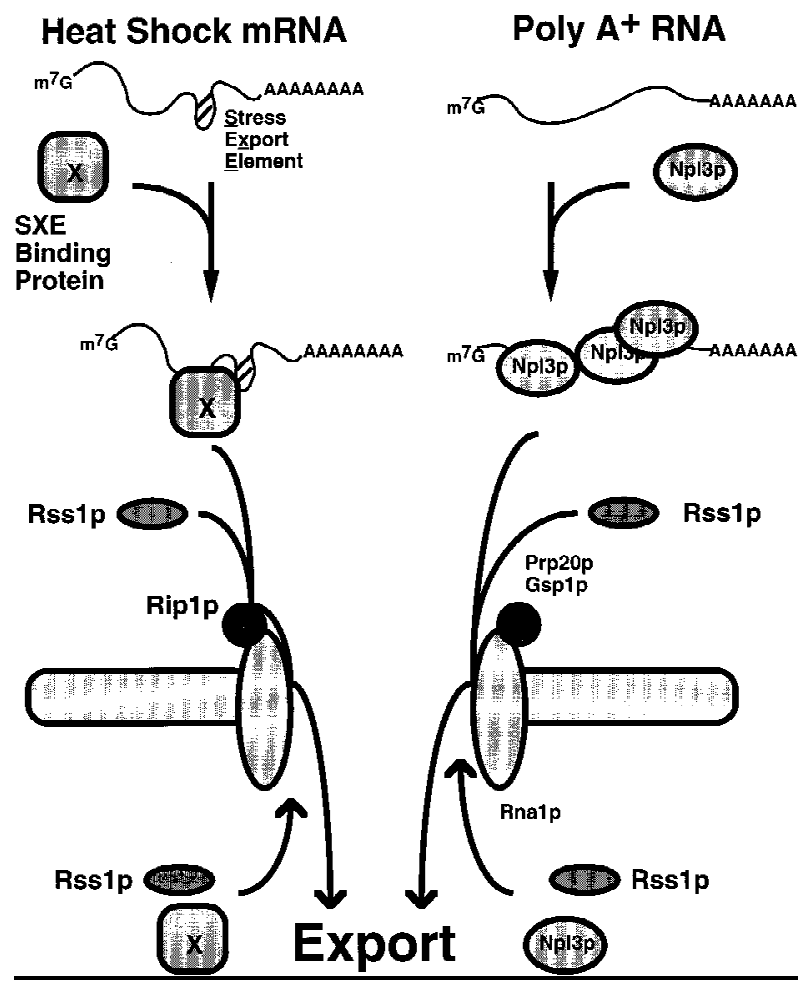

Figure 8. Multiple overlapping pathways for nucleocytoplasmic export of RNA in S. cerevisiae. The pathway for export of poly $(A)^{+}$RN A is shown on the right, and for heat shock mRN As after stress on the left. $X$ is a hypothetical RN A binding, NEScontaining protein that recognizes specific elements in heat shock mRNAs. The subset of nucleoporins essential for both general export of poly $(A)^{+}$RN A under normal conditions and for export of heat shock mRNAs after stress is not shown. 
whether a block in RN A export is complete or partial, as nuclear signals for poly $(A)^{+}$RN A differ only modestly when there is a complete versus incomplete block in RNA export. In addition, it is difficult to distinguish between low concentrations of cytoplasmic RNA and background fluorescence in in situ hybridization (Fay et al. 1997).

The second assay uses pulse-labeling of proteins. This assay complements the in situ hybridization assay, as it readily detects increased production of heat shock proteins, even when there is a partial block in export of heat shock mRNAs. However, it provides no information about the extent to which heat shock mRN As are accumulating in nuclei under various conditions. U sing both assays to examine RNA distribution and protein synthesis in various mutant strains and under various environmental conditions has allowed us to determine whether various gene products are required for export of heat shock mRN As following stress.

The radiolabeling assay also demonstrated that export of mRNAs encoding other classes of heat shock proteins (e.g., Hsp104p and Hsp82p) occurred preferentially following stress and was dependent on the same factors (Riplp, Rsslp/Glelp) and nucleoporins (Rat7p/ N up159p, Rat2p/N up120p and N up145p; Saavedra et al. 1996) as export of SSA4 and SSA 1 mRN As. Thus, heat shock mRN As as a class appear to share an RNA export mechanism. Stutz and Rosbash observed a partial reduction in Rev-dependent export in yeast cells lacking Riplp (Stutz and Rosbash 1994; Stutz et al. 1995), suggesting that Rev mediates export of RRE-containing RNAS through both Riplp-dependent and Riplp-independent pathways. Coupled with the observation that the Rev NES can inhibit export of $U$ snRNAs and 5S RNAs in Xenopus, these results suggest that a Riplp-dependent RNA export pathway is used for export of both heat shock mRNAs following stress and for other classes of RNA (perhaps 5S RN A) but that a separate pathway, independent of Riplp, is available, at least under normal growth conditions, for export of those classes of RNA that use the Riplp-dependent pathway during normal growth.

Inhibition of export of heat shock mRNAs by high-level expression of HIV-1 Rev

The partial inhibition of SSA 4 mRNA export when Rev was expressed from a strong inducible promoter (Fig. 6) further strengthens the hypothesis that heat shock mRN As exit the nucleus via a pathway that is distinct from that normally used for $\operatorname{pol} y(A)^{+}$RN A export. What might be the mechanism by which Rev expression partially inhibits export of heat shock mRNAs? Because wild-type Rev, but not the M 10 mutant, interacts with Riplp in the two-hybrid system, high-level expression of Rev could titrate Riplp, thereby reducing export of heat shock mRN As. However, it now appears that the interaction of Rev and Riplp may be indirect, as two-hybrid interactions between Rev and Riplp were eliminated by loss-of-function mutations in Crmlp (M. N eville et al.
1997). Most likely, Rev titrates one or more cellular NES-binding proteins. We tested whether overexpression of Rsslp/Glelp, which contains a Leu-rich NES similar to Rev's, would affect RNA export but saw no effect on heat shock mRNA export induced following a shift to $42^{\circ} \mathrm{C}$ or on poly $(\mathrm{A})^{+} \mathrm{RN} \mathrm{A}$ export at $23^{\circ} \mathrm{C}$ or $37^{\circ} \mathrm{C}$ (C. Heath and C. Cole, unpubl.). Although Rev expression had no effect on export of poly $(A)^{+}$RN A within the first $4 \mathrm{hr}$ of induction (Fig. 6C), cells containing either Rev or the M 10 mutant under control of the GAL10 promoter failed to form colonies on galactose plates, indicating eventual growth inhibition by both Rev and M 10 (C. Hammell and C. Cole, unpubl.). In contrast, little or no growth inhibition was seen when Rsslp was expressed from a $2 \mu$ plasmid, or when cells containing a gal actose-inducible RSS1 plasmid were grown on galactose (Del Priore et al. 1996; C. Hammell, C. Heath, and C. Cole, unpubl.). Possibly Rss1p/Glelp levels never reach those attained by Rev or M 10. Alternatively, Rev may titrate a critical cellular factor that does not interact with Rsslp/Glelp. A nother possibility is that Rev interacts more strongly with a factor that al so interacts with Rsslp/Glelp.

Interestingly, Rsslp/Glelp is required for both bulk $\operatorname{poly}(\mathrm{A})^{+}$RNA export under normal growth conditions (Del Priore et al. 1996; Murphy and Wente 1996) and export of heat shock mRN As after stress (Fig. 7). Because Rsslp/Glelp contains an NES similar to that of HIV-1 Rev (Murphy and Wente 1996), this protein is most likely a soluble export factor that shuttles between the nucleus and the cytoplasm. Because ts mutations of RSS1 affect heat shock export dramatically (Fig. 7), we suspect that Rsslp/Glelp plays a similar role in export of all mRNAs, and perhaps in export of other classes of RNA as well.

Following the observation of Stutz et al. (this issue), we found that rss1-37 was synthetically lethal with disruption of RIP1 (C. Heath and C. Cole, unpubl.). This means that in the presence of ts alleles of RSS1, Riplp becomes essential for growth even at the permissive temperature $\left(23^{\circ} \mathrm{C}\right)$. This could reflect a nonessential role for Riplp during normal mRNA export. However, there are other possible explanations. We do not yet know whether Rsslp is important for export of other classes of RNA, and it could well be involved in all RN A export. A ssays to examine export of other classes of RN A in S. cerevisiae have not yet been devel oped. Some RN As could exit the nucleus using both Riplp-dependent and Riplp-independent pathways. If cells Iack Riplp, export solely through the other pathway may be insufficient to allow growth in the presence of mutant alleles of RSS1. Riplp may be a structural component of NPCs, most likely anchored within NPCs through its unique carboxyl terminus. N PCs lacking Riplp may be structurally altered so that export efficiency is compromised, perhaps through important binding sites on certain nucleoporins becoming less accessible. Under these conditions, mutations of Rsslp, or other factors important for RNA export, might readily lead to insufficient export under permissive conditions, and thus to the observed synthetic 
lethality. The observation that the carboxy-terminal domain of Riplp, lacking all nucleoporin repeats, suppresses the synthetic lethality between $\Delta$ ripl and temperature-sensitive mutations of RSS1 (Stutz et al. 1997) is consistent with this explanation. Murphy and Wente (1996) isolated GLE1/RSS1 because of its synthetic lethality with a disruption of NUP100, which encodes a nonessential nucleoporin. We tested $\Delta$ nup100 cells for defects in export of heat shock mRNA after stress and saw no differences from wild-type; the same result was obtained with disruption of NUP2, another nonessential nucleoporin (C. Heath, C. Hammell, and C. Cole, unpubl.).

Several important questions remain regarding differential export of mRNA following stress. One concerns the mechanism by which export of most poly(A $)^{+}$RNAs (Saavedra et al. 1996) and import of some nuclear proteins (Liu et al. 1996; Saavedra et al . 1996) are blocked. In addition, we do not know whether the pathway used for export of heat shock mRNAs following stress contains any components that must be activated for the pathway to function. Although we have reported that the Gsplp/ Ran system is not required for export of heat shock mRN As after stress (Saavedra et al. 1996), recent observations in our laboratory indicate that this system remains functional under these conditions, so its inactivation does not appear to be part of the mechanism for altering nucleocytoplasmic transport fol lowing stress (C. Saavedra, C. Hammell, and C. Cole, unpubl.). A nother question concerns the nature of the factors that recognize heat shock mRN As and presumably play a critical role, analogous to that of $\mathrm{Npl} 3 p$ for $\operatorname{poly}(\mathrm{A})^{+} \mathrm{RNA}$, in mediating the export of heat shock mRNAs. Finally, it will be necessary to determine the identity of the factors that play the same role for export of heat shock mRN A that the Ran/Gsplp system performs for export of most classes of RNA.

\section{Materials and methods}

Strains, plasmids, and growth conditions

Yeast strains are listed in Table 1. Except where noted, cells were grown to early exponential phase at $23^{\circ} \mathrm{C}$ in YPD-rich medium or in synthetic complete medium lacking leucine (SC - Leu) or uracil (SC -Ura) (Rose et al. 1989). For induction of the heat shock response, cells in the exponential phase of growth $\left(5 \times 10^{6}\right.$ to $2 \times 10^{7}$ cells $\left./ \mathrm{ml}\right)$ were transferred to water baths at the appropriate temperature. In some experiments, the stress response was also induced by the addition of ethanol to $10 \%$ (vol/vol). Strains FY23 and FY86, derived from S288C, were used as wild types (Winston et al. 1995). Y east transformations were performed by el ectroporation using a Gene-Pulser (Bio-Rad Laboratories, M elville, NY); cells were allowed to recover in rich medium containing $1 \mathrm{~m}$ sorbitol at $23^{\circ} \mathrm{C}$ for at least $1 \mathrm{hr}$ before plating. E. coli strain $\mathrm{DH} 5 \alpha$ was used for most cloning procedures. Plasmids used in these studies are listed in Table 2. A strain containing an integrated copy of the npl3-17 allele was generously provided by $\mathrm{M}$ argaret Lee and Pamela Silver (Dana Farber Cancer Institute, Boston, MA).

Construction of a strain disrupted for RIP1

A PCR-based gene deletion approach (Baudin et al. 1993) was used to disrupt the RIP1 gene. We generated a HIS3 cassette by PCR amplification that was flanked at its ends by 45 nucleotides identical to sequences just upstream and downstream of the RIP1 open reading frame (ORF). The upstream oligonucleotide sequence was 5'-GTAATGTCAGCTTTCGGTAACCCATTCACGTCGGGTGCTAAGCCTGGCCTCCTCTAGTACACTC-3' and the downstream oligonucleotide sequence was 5'-CACTTACTATGCAACCAATGCAGGTGGTGGAGGTATATCAGGGTCGCGCGCCTCGTTCAGAATG$3^{\prime}$. For both oligonucleotides, the last 19 nucleotides are homologous to the HIS3 selectable marker. We used $20 \mathrm{ng}$ of the HIS3-containing plasmid pBM 2815 (obtained from P. Silver, Dana Farber Cancer Institute, Boston, MA) to generate the deletion construct in the PCR reaction. The $50 \mu \mathrm{l} P C R$ reaction consisted of $1 \times P C R$ buffer ( $10 \mathrm{~mm}$ Tris- $\mathrm{HCl}, 15 \mathrm{~mm} \mathrm{M} \mathrm{gCl}, 500$ $\mathrm{mm} \mathrm{KCl}$ at $\mathrm{pH}$ 8.3), $0.8 \mathrm{~mm} \mathrm{dNTP}(0.2 \mathrm{~mm}$ each dATP, dGTP, dCTP, and dTTP), $1 \mu \mathrm{m}$ of the upstream and downstream oligonucleotides, and 2 units of Taq DNA polymerase (Boehringer $M$ annheim Biochemicals, Indianapolis, IN ). The reaction was subjected to a 30-cycle amplification consisting of $1.5 \mathrm{~min}$ at $94^{\circ} \mathrm{C}, 2.0 \mathrm{~min}$ at $50^{\circ} \mathrm{C}$, and $2.0 \mathrm{~min}$ at $72^{\circ} \mathrm{C}$. The PCR product was transformed into a wild-type haploid strain FY86, containing the deletion allele his $3 \Delta 200$. The flanking upstream and downstream sequences target the del etion construct to the RIP1 such that its ORF is replaced with HIS3 by homologous recombination. Recombinants were selected on SC $-\mathrm{His}$ plates, and recombination was verified by PCR.

Table 1. Yeast strains used in this study

\begin{tabular}{|c|c|c|}
\hline Strain & Genotype & Source \\
\hline FY23 & MATa trp1 $\Delta 63$ leu2 $\Delta 1$ ura3-52 & Winston et al. (1995) \\
\hline FY 86 & MAT $\alpha$ his3 $\Delta 200$ leu2 $\Delta 1$ ura3-52 & Winston et al. (1995) \\
\hline ACY 1 & MAT $\alpha /$ MATa his3 $\Delta 200 /$ his3 $\Delta 200$ leu2 $\Delta 1 /$ leu2 $\Delta 1$ ura3-52/ura3-52 trp1 $\Delta 63 / T R P 1$ & $\begin{array}{l}\text { A nita Corbett (Dana Farber } \\
\text { Cancer Institute, Boston, } \\
\text { MA) }\end{array}$ \\
\hline CHY 119 & MAT $\alpha$ rip1::HIS3 his3 $\Delta 200$ ura3-52 leu2 $\Delta 1$ & this study \\
\hline PSY 361 & MAT $\alpha$ npl3-1 ura3-52 leu2-3,112 trp1- $\Delta 901$ ade2-101 his3 $\Delta 200$ his4-519 lys2-801 & $\begin{array}{l}\text { Pamela Silver (Dana Farber } \\
\text { Cancer Institute, Boston, } \\
\text { MA) }\end{array}$ \\
\hline PSY 1026 & MAT $\alpha$ np13-17 ade2-101 can1-100 his3 $\Delta 200$ leu2 $\Delta 1$ lys1-1 ura3-52 ade8 & $\begin{array}{l}\text { Margaret Lee (Dana Farber } \\
\text { Cancer Institute, Boston, } \\
\text { MA) }\end{array}$ \\
\hline
\end{tabular}


Table 2. Plasmids used in this study

\begin{tabular}{|c|c|c|c|}
\hline Plasmid & Markers & Comments & Source \\
\hline Ylplac211 & URA3 Amp ${ }^{R}$ & integration vector & \\
\hline YCplac33 & ARS/CEN URA3 Amp ${ }^{R}$ & low-copy episomal vector & \\
\hline YCplac111 & ARS/CEN LEU 2 Amp ${ }^{R}$ & low-copy episomal vector & \\
\hline pVDP21 & RSS1 ARS/CEN LEU 2 Amp ${ }^{R}$ & & Del Priore et al. (1996) \\
\hline pVDP29 & rss1-37 ARS/CEN LEU 2 Amp & temperature-sensitive allele of RSS1 & Cole laboratory \\
\hline pEC 702 & $2 \mu$ LEU $2 \mathrm{Amp}^{\mathrm{R}} \mathrm{SSA} 4$ & SSA4 gene in Yep351 & $\begin{array}{l}\text { E. Craig (University of } \\
\text { Wisconsin, M adison) }\end{array}$ \\
\hline (GAL1-SSA4)2 & $2 \mu$ LEU 2-d Amp ${ }^{R}$ Tet $^{R}$ & Gal-inducible SSA4 & E. Craig \\
\hline pDAD-1 & $2 \mu$ URA3 Amp ${ }^{R}$ Tet $^{R}$ & $\begin{array}{l}\text { GAL1 promoter vector, polylinker } \\
\text { PHO } 5 \text { terminator }\end{array}$ & $\begin{array}{l}\text { G. Fink (Whitehead } \\
\text { Institute, Cambridge, MA) }\end{array}$ \\
\hline pCS120 & $\begin{array}{l}\text { HIV-1 Rev open reading frame } \\
\text { in pDAD-1 }\end{array}$ & Gal-inducible Rev expression vector & this study \\
\hline pCS121 & $\begin{array}{l}\text { HIV-1 M } 10 \text { mutant open } \\
\text { reading frame in pDAD-1 }\end{array}$ & Gal-inducible M 10 expression vector & this study \\
\hline
\end{tabular}

Construction of plasmids for inducible expression of HIV-1 Rev and M10 mutant Rev

Plasmids containing the ORFs of Rev and M10 mutant Rev, fused to glutathione S-transferase, were obtained from M ichael Malim (University of Pennsylvania, Philadel phia). The ORFs of wild-type and M 10 mutant Rev were amplified by PCR, and the resulting 350-bp DNA fragments were subcloned into pDAD-1 between the HindlII and EcoRI sites in its polylinker region, thereby placing Rev and M 10 Rev under control of the yeast GAL10 promoter.

\section{Construction of the RSS1 temperature-sensitive alleles}

The RSS1 temperature-sensitive alleles were made using PCR mutagenesis (Cadwell and Joyce 1992). The RSS1 gene between base pair 246 and 1966 was PCR amplified using the following primers: 5'-GGTATATAATTGATAACAAGAGAATCGTCGGGCCGTTGCTACAGGATATTC-3' and 5'-GTGTATTAGCATTTTTAATGTGCATATATAAGTTCAGAATTTTC-3'. The following changes were made to the standard PCR conditions: 7

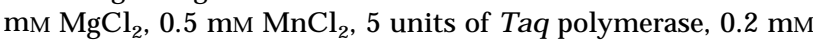
dGTP, $0.2 \mathrm{~mm}$ dATP, $1 \mathrm{~mm}$ dCTP, and $1 \mathrm{~mm}$ dTTP. These changes led to enhanced misincorporation of nucleotides. pVDP21 was digested with Xhol(318) and BspEI(1909), and the gapped vector was gel-isolated. A mixture of the vector and the PCR fragment was transformed into VDPY 111, and the transformants were plated on SC - Leu medium. Colonies that came up on the SC - Leu plates were replica plated onto 5-FOA containing medium to sel ect for loss of the plasmid-borne wild-type copy of RSS1. The colonies that grew on 5-FOA were replica plated to SC - Leu plates and incubated at $23^{\circ} \mathrm{C}$ and $37^{\circ} \mathrm{C}$. M utants that grew at $23^{\circ} \mathrm{C}$ but not at $37^{\circ} \mathrm{C}$ were sel ected for further studies.

In situ hybridization assays

In situ hybridization assays to detect poly(A) $)^{+}$RNA or SSA 4 RNA were performed as described previously (Amberg et al. 1992; Gorsch et al. 1995; Saavedra et al. 1996).

In vivo protein labeling

Cells were grown at $23^{\circ} \mathrm{C}$ in $\mathrm{SC}-\mathrm{Met}$ and containing 0.85 grams/liter of yeast nitrogen base without amino acids and ammonium sulfate and 3.3 grams/liter of yeast nitrogen base with- out amino acids. Cells were grown to an $\mathrm{OD}_{600}$ of 0.5 , collected by centrifugation, washed, and resuspended in one tenth the original volume in medium lacking sulfate. After incubation for $10 \mathrm{~min}$ at $23^{\circ} \mathrm{C}, 1-\mathrm{ml}$ al iquots were either maintained at $23^{\circ} \mathrm{C}$ or shifted to $42^{\circ} \mathrm{C}$ for 15,30 , or $60 \mathrm{~min}$. Cultures were radi ol abel ed by addition of $100 \mu \mathrm{Ci} / \mathrm{ml}$ of Trans- ${ }^{35} \mathrm{~S}$-label (ICN Pharmaceuticals) for the final $10 \mathrm{~min}$ of the incubation period. Incorporation of radiolabel was stopped by the addition of $9 \mathrm{ml}$ of ice-cold sodium azide $(20 \mathrm{~mm})$. Samples were then washed in sodium azide and resuspended in $0.2 \mathrm{ml}$ of buffer A (Bram and Kornberg 1985). Cells were lysed with 0.75 grams of $0.45-\mathrm{mm}$ gl ass beads. Supernatant was removed and centrifuged at $12,000 \mathrm{~g}$ for $20 \mathrm{~min}$. Total soluble protein was measured using a BioRad protein assay kit. Five micrograms of total soluble protein was boiled for 3 min in $5 \times$ loading buffer (Bram and Kornberg 1985) and fractionated on a 7.5\% SDS-polyacrylamide gel (Laemmli 1970). Gels were then dried and exposed to a Phosphor screen (M olecular Dynamics) and imaged using ImageQuant software (M olecular Dynamics).

\section{Western analyses}

Cells were grown to a total $\mathrm{OD}_{600}$ of 0.75 , pelleted by centrifugation at $2500 \mathrm{rpm}$ for $2.5 \mathrm{~min}$, and washed once with water. Two hundred micrograms of acid-washed gl ass beads and $200 \mu \mathrm{l}$ of hot sample buffer $(62.5 \mathrm{~mm}$ TrisCl at pH $6.8,2 \% \mathrm{SDS}, 10 \%$ glycerol, $8 \mathrm{~m}$ urea, 0.72 м 2-mercaptoethanol, 0.05\% bromophenol blue) were added to the cell pellets. After brief vortexing, cells were transferred to a boiling water bath for $3 \mathrm{~min}$. Cells were then lysed as follows: $10 \mathrm{sec}$ vortexing and $50 \mathrm{sec}$ incubation in the boiling water bath, repeated five times over $5 \mathrm{~min}$. The supernatant was then transferred to a clean Eppendorf tube, and equal volumes of cell lysate were loaded onto a $10 \%$ polyacrylamide-SDS gel. Electrophoresis was carried out at $200 \mathrm{~V}$ for $\sim 50 \mathrm{~min}$. Proteins in the gel were transferred to a PVDF membrane by electroblotting overnight at $100 \mathrm{~mA}$ in a cold room. The membrane was washed briefly with $1 \times$ phosphatebuffered saline (PBS), $0.1 \%$ Tween 20 solution (solution A), and then blocked for $1 \mathrm{hr}$ with $1 \times \mathrm{PBS}, 0.1 \%$ Tween 20 , and $5 \%$ nonfat milk solution (solution $B$ ). The membrane was then incubated with anti-Rev antiserum (kindly provided by Dr. Michael Malim, Howard Hughes Medical Institute, University of Pennsylvania, Philadel phia) at a 1:5000 dilution in solution B for $2 \mathrm{hr}$ foll owed by four washes of $10 \mathrm{~min}$ each with solution A. The membrane was then incubated with anti-rabbit antibody 
coupled to horseradish peroxidase (Amersham, Inc., Arlington Heights, IL), diluted 1:3000 in solution B for $1 \mathrm{hr}$. Washes were performed as described above. Signal was developed with the ECL kit (Amersham, Inc.) according to the manufacturer's directions.

\section{Analysis of SSA 4 mRNA levels by primer extension}

Both wild-type and $\Delta$ ripl cells were grown to an $\mathrm{OD}_{600}$ of 0.5 . RN A extractions were performed as described by Pikielny and Rosbash (1985). The total RN A isolated from each sample was dissolved in $20 \mu \mathrm{l}$ of distilled water. Identical al iquots from each sample were subjected to el ectrophoresis in a $1 \%$ agarose gel and stained with ethidium bromide to permit visualization of rRNAs. A primer with the sequence GTTGTACCTAAATCAATACC was used to specifically measure SSA 4 mRN A levels. LYS7 mRN A levels were measured with primer AGGGGCTACTGAGCTTTCCA. Primer extension assays were performed using $6 \mu \mathrm{l}$ of each isolated RNA sample. Both primers were added to each RNA sample and primer extension performed as described (Pikielny and Rosbash 1985). Extension products were analyzed on a $12 \%$ denaturing polyacrylamide gel. The relative levels of extension products were quantified using a Molecular Dynamics Phosphorlmager using ImageQuant software.

\section{Acknowledgments}

We thank Elizabeth Craig, Margaret Lee, and Pamela Silver for plasmids and strains; Michael Malim for antibodies and plasmids; Veronica Del Priore for the rss1-37 temperature-sensitive mutant strain; Francoise Stutz and Michael Rosbash for discussions and sharing results of their experiments prior to publication; and members of our laboratory for discussions and advice. We thank Pamela Silver and Hildur Colot for critical review of the manuscript. This work was supported by a grant from the N ational Institute of General Medical Sciences, N ational Institutes of Health to C.N.C. (GM 33998) and by a core grant to the Norris Cotton Cancer Center, Dartmouth Hitchcock Medical Center, from the N ational Cancer Institute (CA-16038).

The publication costs of this article were defrayed in part by payment of page charges. This article must therefore be hereby marked "advertisement" in accordance with 18 USC section 1734 solely to indicate this fact.

\section{References}

Adam, S.A., R.S. Marr, and L. Gerace 1990. Nuclear protein import in permeabilized mammalian cells requires soluble cytoplasmic factors. J. Cell Biol. 111: 807-816.

Aitchison, J.D., G. Blobel, and M.P. Rout. 1995. Nup120p: A yeast nucleoporin required for N PC distribution and $\mathrm{mRN} A$ transport. J. Cell Biol. 131: 1659-1675.

Amberg, D.A., A.L. Goldstein, and C.N. Cole. 1992. Isolation and characterization of RAT1, an essential gene of Saccharomyces cerevisiae required for the efficient nucleocytoplasmic trafficking of mRNA. Genes \& Dev. 6: 1173-1189.

Amberg, D.C., M. Fleischmann, I. Stagljar, C.N. Cole, and M. A ebi. 1993. Nuclear PRP20 protein is required for $\mathrm{mRNA}$ export. EMBO J. 12: 233-241.

Baudin, A., O. Ozier-Kalogeropoulos, A. Denouel, F. Lacroute, and C. Cullin. 1993. A simple and efficient method for direct gene deletion in Saccharomyces cerevisiae. Nucleic Acids Res. 21: 3329-3330.

Bogerd, H.P., R.A. Fridell, S. Madore, and B.R. Cullen. 1995. Identification of a novel cellular cofactor for the Rev/Rex class of retroviral regulatory proteins. Cell 82: 485-494.

Bram, R.J. and R.D. Kornberg. 1985. Specific protein binding to far upstream activating sequences in polymerase II promoters. Proc. Natl. Acad. Sci. 82: 43-47.

Cadwell, R.C. and G.F. Joyce. 1992. Randomization of genes by PCR mutagenesis. PCR Methods \& Applic. 2: 28-33.

Corbett, A.H. and P.A. Silver. 1997. N ucleocytoplasmic transport of macromolecules. Microbiol. Mol. Biol. Rev. 61: 193211.

Davis, L.I. 1995. The nuclear pore complex. Annu. Rev. Biochem. 64: 865-896.

DeHoratius, C. and P. A. Silver. 1996. N uclear transport defects and nuclear envelope alterations are associated with mutation of the Saccharomyces cerevisiae NPL4 gene. Mol. Biol. Cell 7: 1835-1855.

Del Priore, V., C.A. Snay, A. Bahr, and C.N. Cole. 1996. Identification of RSS1, a high-copy extragenic suppressor of the rat7-1 temperature-sensitive allele of the Saccharomyces cerevisiae RAT7/NUP159 nucleoporin. Mol. Biol. Cell 7: 1601-1621.

Dockendorff, T.C., C.V. Heath, A.L. Goldstein, C.A. Snay, and C.N. Cole. 1997. C-terminal truncations of the yeast nucleoporin N up145p produce conditional mRNA export defects and al terations to nuclear structure. [Published erratum in Mol. Cell. Biol. 17: 2347-2350] Mol. Cell. Biol. 17: 906-920.

Doye, V., R. Wepf, and E.C. Hurt. 1994. A novel nuclear pore protein N up133p with distinct roles in poly $(A)^{+}$RN A transport and nuclear pore distribution. EMBO J. 13: 6062-6075.

Fabre, E., W.C. Boelens, C. Wimmer, I.W. M attaj, and E.C. Hurt. 1994. N up145p is required for nuclear export of mRN A and binds homopolymeric RNA in vitro via a novel conserved motif. Cell 78: 275-289.

Fay, F.S., K.L. Taneja, S. Shenoy, L. Lifshitz, and R.H. Singer. 1997. Quantitative digital analysis of diffuse and concentrated nuclear distributions of nascent transcripts, SC 35 and poly(A). Exp. Cell Res. 231: 27-37.

Fischer, U., S. Meyer, M. Teufel, C. Heckel, R. Lührmann, and G. Rautmann. 1994. Evidence that HIV-1 Rev directly promotes the nuclear export of unspliced RNA. EMBO J. 13: 4105-4112.

Fischer, U., J. Huber, W.C. Boelens, I.W. Mattaj, and R. Lührmann. 1995. The HIV-1 Rev activation domain is a nuclear export signal that accesses an export pathway used by specific cellular RN As. Cell 82: 475-483.

Forrester, W., F. Stutz, M. Rosbash, and M. Wickens. 1992. Defects in mRNA $3^{\prime}$-end formation, transcription initiation, and mRNA transport associated with the yeast mutation prp20: Possible coupling of mRNA processing and chromatin structure. Genes \& Dev. 6: 1914-1926.

Fridell, R.A., H.P. Bogerd, and B.R. Cullen. 1996. N uclear export of late HIV-1 mRNAs occurs via a cellular protein export pathway. Proc. Natl. Acad. Sci. 93: 4421-4424.

Fritz, C.C. and M.R. Green. 1996. HIV Rev uses a conserved cellular protein export pathway for the nucleocytoplasmic transport of viral RN As. Curr. Biol. 6: 848-854.

Fritz, C.C., M .L. Zapp, and M .R. Green. 1995. A human nucleoporin-like protein that specifically interacts with HIV Rev. Nature 376: 530-533.

Goldstein, A.L., C.A. Snay, C.V. Heath, and C.N. Cole. 1996. Pleiotropic nuclear defects associated with a conditional allele of the novel nucleoporin Rat9p/N up85p. Mol. Biol. Cell 7: 917-934.

Görlich, D. and I.W. Mattaj. 1996. Protein kinesis-Nucleocytoplasmic transport. Science 271: 1512-1518.

Gorsch, L.C., T.C. Dockendorff, and C.N . Cole. 1995. A conditional allele of the novel repeat-containing yeast nucleoporin 
RAT7/NU P159 causes both rapid cessation of mRN A export and reversible clustering of nuclear pore complexes. J. Cell Biol. 129: 9399-9355.

Heath, C.V., C.S. Copeland, D.C. Amberg, V. Del Priore, M. Snyder, and C.N. Cole. 1995. N uclear pore complex clustering and nuclear accumulation of poly(A) $)^{+}$RNA associated with mutations of the Saccharomyces cerevisiae RAT2/ NU P120 gene. J. Cell Biol. 131: 1677-1697.

Hicks, G.R. and N.V. Raikhel. 1996. Protein import into the nucleus: An integrated view. Annu. Rev. Cell Biol. 11: 155188.

Hurwitz, M.E. and G. Blobel. 1995. N UP82 is an essential yeast nucleoporin required for poly $(\mathrm{A})^{+} \mathrm{RNA}$ export. J. Cell Biol. 130: 1275-1281.

Jarmolowski, A., W.C. Boelens, E. Izaurral de, and I.W. Mattaj. 1994. N uclear export of different classes of RN A is mediated by specific factors. J. Cell Biol. 124: 627-635.

Jost, H.J. and S. Lindquist. 1988. Translation of unspliced transcripts after heat shock. Science 242: 1544-1548.

Kadowaki, T., Y. Zhao, and A.M. Tartakoff. 1992. A conditional yeast mutant deficient in mRNA transport from nucleus to cytoplasm. Proc. Natl. Acad. Sci. 89: 2312-2316.

Kraemer, D.M., C. Strambio-de-Castillia, G. Blobel, and M.P. Rout. 1995. The essential yeast nucleoporin NUP159 is Iocated on the cytoplasmic side of the nuclear pore complex and serves in karyopherin-mediated binding of transport substrate. J. Biol. Chem. 270: 19017-19021.

Laemmli, U.K. 1970. Cleavage of structural proteins during the assembly of the head of bacteriophage T4. Nature 227: 680685.

Lee, M., M. Henry, and P.A. Silver. 1996. A protein that shuttles between nucleus and cytopl asm, is an important mediator of mRN A export. Genes \& Dev. 10: 1233-1246.

Li, O., C.V. Heath, D.C. Amberg, T.C. Dockendorff, C.S. Copeland, M. Snyder, and C.N. Cole. 1995. Mutation or deletion of the Saccharomyces cerevisiae RAT3/NUP133 gene causes temperature-dependent nuclear accumulation of poly $(\mathrm{A})^{+}$RNA and constitutive clustering of nuclear pore complexes. Mol. Biol. Cell 6: 401-417.

Lindquist, S. 1986. The heat-shock response. Annu. Rev. Biochem. 55: 1151-1191.

Lindquist, S. and R. Petersen. 1990. Selective translation and degradation of heat-shock messenger RNAs in Drosophila. Enzyme 44: 147-166.

Liu, Y., S. Liang, and A.M. Tartakoff. 1996. Heat shock disassembles the nucleolus and inhibits nuclear protein import and poly(A)+ RN A export. EMBO J. 15: 6750-6757.

Malim, M.H., D.F. McCarn, L.S. Tiley, and B.R. Cullen. 1991. Mutational definition of the human immunodeficiency virus type 1 Rev activation domain. J. Virol. 65: 4248-4254.

Meyer, B.W. and M.H. Malim. 1994. The HIV-1 Rev trans-activator shuttles between the nucleus and cytoplasm. Genes \& Dev. 8: 1538-1547.

Michael, W.M., M. Choi, and G. Dreyfuss. 1995. A nuclear export signal in hnRNP A1: A signal-mediated, temperature dependent nuclear protein export pathway. Cell 83: 415-422.

Moore, M.S. and G. Blobel. 1992. The two steps of nuclear import, targeting to the nuclear envelope and translocation through the nuclear pore, require different cytosolic factors. Cell 69: 939-950.

Morimoto, R.I. 1993. Cells in stress: Transcriptional activation of heat shock genes. Science 259: 1409-1410.

Morimoto, R., A. Tissières, and C. Georgopoulos. 1994. The biology of heat shock proteins and molecular chaperones Cold Spring Harbor Press, Cold Spring Harbor, NY.

Murphy, R. and S.R. Wente. 1996. An RNA-export mediator with an essential nuclear export signal. Nature 383: 357360.

Murphy, R., J.L. Watkins, and S.R. Wente. 1996. GLE2, a Saccharomyces cerevisiae homologue of the Schizosaccharomyces pombe export factor RAE1, is required for nuclear pore complex structure and function. Mol. Biol. Cell 7: 1921-1937.

N eville, M., L. Lee, F. Stutz, L.I. Davis, and M. Rosbash. 1997. Evidence that the importin-beta family member Crmlp bridges the interaction between Rev and the nuclear pore complex during nuclear export in S. cerevisiae. Curr. Biol. (in press).

Nigg, E.A. 1997. N ucleocytoplasmic transport: Signals, mechanisms and regulation. Nature 386: 779-787.

Panniers, R. 1994. Translational control during heat shock. Biochimie 76: 737-747.

Panté, N . and U. A ebi. 1996. M ol ecular dissection of the nuclear pore complex. Crit. Rev. Biochem. Molec. Biol. 31: 153-199.

Pikielny, C.W. and M. Rosbash. 1985. mRN A splicing efficiency in yeast and the contribution of non-conserved sequences. Cell 41: 119-126.

Rose, M.D., F. Winston, and P. Hieter. 1989. Methods in yeast genetics. Cold Spring Harbor Laboratory Press, Cold Spring Harbor, NY.

Saavedra, C., K.-S. Tung, D.C. Amberg, A.K. Hopper, and C.N. Cole. 1996. Regulation of mRN A export in response to stress in Saccharomyces cerevisiae. Genes \& Dev. 10: 1608-1620.

Schlenstedt, G., E. Hurt, V. Doye, and P.A. Silver. 1993. Reconstitution of nuclear protein transport with semi-intact yeast cells. J. Cell Biol. 123: 785-798.

Shiokawa, K. and K.O. Pogo. 1974. The role of cytoplasmic membranes in controlling the transport of nuclear messenger RNA and initiation of protein synthesis. Proc. Natl. Acad. Sci. 71: 2658-2662.

Sierra, J.M. and J.M. Zapata. 1994. Translational regulation of the heat shock response. Mol. Biol. Rep. 19: 211-220.

Siniossogl ou, S., C. Wimmer, M. Rieger, V. Doye, H. Tekotte, C. Weise, S. Emig, A. Segref, and E.C. Hurt. 1996. A novel complex of nucleoporins which includes Sec13p and a Sec13p homolog, is essential for normal nuclear pores. Cell 84: 265275.

Stutz, F. and M. Rosbash. 1994. A functional interaction between Rev and yeast pre-mRN A is related to splicing complex formation. EMBO J. 17: 4096-4104.

Stutz, F., M. N eville, and M. Rosbash. 1995. Identification of a novel nuclear pore-associated protein as a functional target of the HIV-1 Rev protein in yeast. Cell 82: 495-506.

Stutz, S., E. Izaurral de, I. Mattaj, and M. Rosbash. 1996. A role for nucleoporin FG repeat domains in export of human immunodeficiency virus type 1 Rev protein and RN A from the nucleus. Mol. Cell. Biol. 16: 7144-7150.

Stutz, F., J. Kantor, D. Zhang, T. M cCarthy, M. N eville, and M. Rosbash. 1997. The yeast nucleoporin Riplp contributes to multiple export pathways with no essential role for its FGrepeat region.Genes \& Dev. (this issue).

Wente, S.R. and G. Blobel. 1994. NU P145 encodes a novel yeast glycine-leucine-phenylalanine-glycine (GLFG) nucleoporin required for nuclear envelope structure. J. Cell Biol. 125: 955-969.

Winston, F., C. Dollard, and S.L. Ricupero-Hovasse. 1995. Construction of a set of convenient Saccharomyces cerevisiae strains that are isogenic to S288C. Yeast 11: 53-55.

Wong, D.H., A.H. Corbett, H.K. Kent, M. Stewart, and P.A. Silver. 1997. Interaction between the small GTPase Ran/ Gsplp and N tf2p is required for nuclear transport. Mol. Cell. Biol. 17: 3755-3767. 


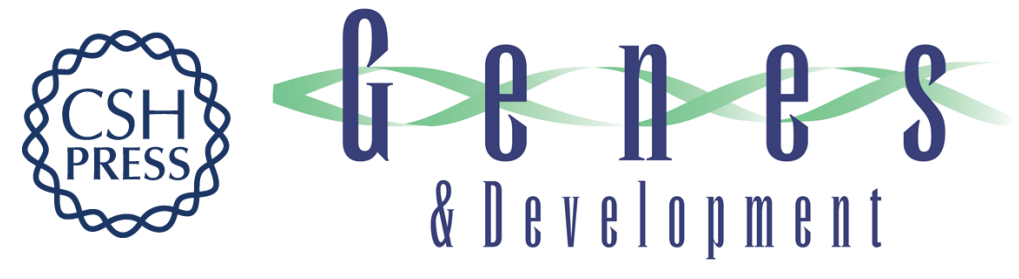

\section{Yeast heat shock mRNAs are exported through a distinct pathway defined by Rip1p}

Claudio A. Saavedra, Christopher M. Hammell, Catherine V. Heath, et al.

Genes Dev. 1997, 11:

Access the most recent version at doi:10.1101/gad.11.21.2845

References This article cites 60 articles, 30 of which can be accessed free at: http://genesdev.cshlp.org/content/11/21/2845.full.html\#ref-list-1

License

Email Alerting

Receive free email alerts when new articles cite this article - sign up in the box at the top Service right corner of the article or click here.

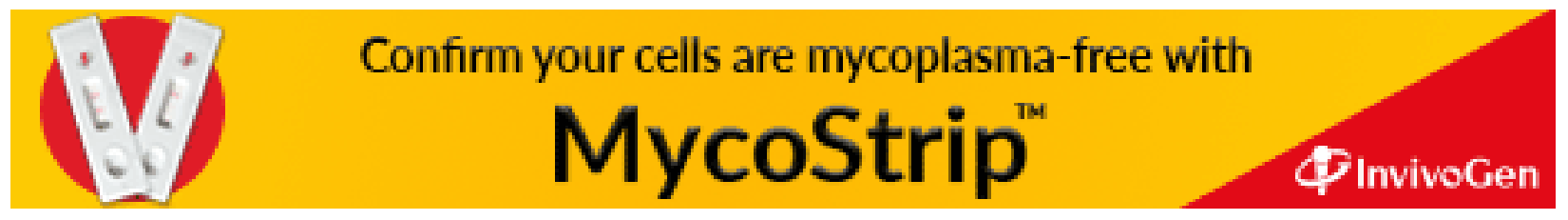

